\title{
From boom to crash: Spanish urban areas in a decade of
}

$$
\text { changes (2001-2011) }
$$

Fernando Gil-Alonso, Jordi Bayona-i-Carrasco, and Isabel Pujadas-i-Rúbies

University of Barcelona, Spain 


\section{Abstract}

This paper has two main aims: on the one hand, it provides an overview of recent metropolitan area population changes in Spain and assesses their spatial patterns through a typology and on the other hand, it analyses the impact of the current economic crisis on the aforementioned trends. The main source used is the Padrón continuo, the local continuous registration system providing official data updated every year on 1 January. Regarding metropolitan area delimitation, we have decided to use that employed by the Atlas de las Áreas Urbanas de España and to situate the population threshold at 500,000 inhabitants. Fifteen urban areas satisfied the requirements. Therefore, this paper analyses, for the 2001-2011 decade, population growth and urban expansion in the 15 Spanish largest metropolitan areas. In the first phase, suburbanisation intensified while the areas simultaneously received significant international migration inflows. The latter compensated Spaniards' exit flows from core cities, which increased their population again. The economic crisis, which began in 2008, and its significant impact on the real estate sector, drew an end to this urban expansion and growth period, as it seems to have slowed Spanish metropolitan area growth and restrained suburbanisation dynamics. Consequently, in recent years, residential mobility has decreased and metropolitan areas have entered a new phase characterised by a reduction of both foreign immigration inflows and Spaniards' 
movements away from core cities. Therefore, with few exceptions, urban centres are currently once again gaining Spanish residents or at least have stopped losing them.

\section{Keywords}

Foreign immigration, suburbanisation, urban growth, metropolitan areas, crisis, Spain

\section{Introduction}

Driven by economic growth, Spain has changed from a traditionally emigration to an immigration country (Muñoz and Izquierdo, 1989). More specifically, since the late $20^{\text {th }}$ century, Spain has undergone an abrupt and unexpected foreign immigration boom (Izquierdo and López de Lera, 2003; Reques and De Cos, 2004; Domingo and GilAlonso, 2007), becoming during some years the country with the largest foreign migration inflows in Europe. As a consequence, between 2001 and 2011, registered inhabitants increased from $41,116,842$ to $47,190,493$. This phenomenon is so exceptional that these extra 6 million inhabitants represent the highest absolute and relative (14.8\%) rise in a decade since 1900 . Foreigners played a crucial role in this process, being approximately responsible for -leaving naturalizations and children from mixed marriages aside- at least three quarters of the growth. Their numbers multiplied 
by six, increasing from 1,370,657 in 2001 to 5,751,487 in 2011, or in other words, from corresponding to $3.3 \%$ of the population to representing $12.2 \%$ of it.

Foreigners' uneven spatial distribution throughout Spain has implied that, despite touching the whole territory, certain areas -particularly urban ones- have been more affected than others by their arrival (Bayona et al., 2011). The paper focuses on immigrants' effects on the fifteen largest Spanish metropolitan areas, that is to say, those with more than 500,000 inhabitants. More specifically, the paper firstly analyses their growth and suburban expansion during the economic boom phase, focusing on the impact of foreign immigration on both core cities and fringe areas; and then, it assess the consequences that the current deep economic crisis has had on these processes.

In the mid 1990s, suburbanisation and metropolitan expansion were the two main features defining the Spanish urban system. While urban peripheries were rapidly expanding, most metropolitan centres were losing population and their residents progressively ageing (Nel·lo, 2007; Feria, 2011). Then, particularly from 2000 onwards, core depopulation was abruptly interrupted and urban centres started to gain population once again. What would be the causes of this new trend? As López-Gay (2011) states, core cities are gradually losing less Spanish population because urban centres are becoming increasingly attractive, particularly for young people looking for jobs, better education or an urban life style. Another possible reason behind this increasing attractiveness is population and household changes associated to the so-called 'second 
demographic transition'. This process would lead to increasing numbers of one-person and one-parent households, more unmarried couples because of extended cohabitation, and more stepfamilies due to increasing divorces. These new types of households are relatively more frequent in city centres than traditional families with children, which are more attracted by suburbs (López-Villanueva and Pujadas, 2011). For instance, in 2010 one out of three households in Barcelona are one-person ones (30.6\% to be more exact, compared to $26.1 \%$ in 2001 and only $18.1 \%$ in 1991), making it the most common type in the city. Similar trends are found in Madrid and other large cities. Metropolitan area population segregation by household type is actually intensified by residential mobility as families with children tend to move to the periphery where they can more easily find adequate housing (Frey y Kobrin, 1982; Bonvalet y Leliévre, 1997).

Nevertheless, Spain’s large city population recovery has basically been driven by a surge of foreign migrants, as incoming foreigners have compensated constant Spanish population loss (Bayona and Gil-Alonso, 2012a). At the same time, this international inflow has fed and intensified suburbanisation flows, mainly made up of autochthonous people though also increasingly of foreigners.

Nevertheless, this phenomenon has not had the same magnitude throughout all the metropolitan areas. While many of them have been considered by foreign immigrants as their main settlement points (but also as gateways, moving later elsewhere), others have hardly received any demographic impact. 
The demographic and geographic urban expansive phase is abruptly interrupted in 2008, when the global economic crisis starts affecting Spain, where it is worsened by the local real estate market collapse, after the 1996-2007 inflationist period (Gil-Alonso et al., 2012). Even though foreign inflows have, since then, decreased, their impact on the urban areas is, again, probably very heterogeneous. As this latter period has already lasted for some years, we belief that some conclusions can already start to be extracted both from urban changes introduced by high immigration years and from the effects of the economic crisis on urban growth.

The paper starts with a conceptual section which justifies the theoretical framework -the Van den Berg et al. (1982) cyclical urbanisation model-, the data sources and the urban area definition used. As for the empirical analysis itself, it is divided into two main sections. The first starts by analysing rising metropolitan population numbers, and focuses on the role of foreign immigration in it. Differences in core city and fringe area growth between Spanish metropolitan areas are then studied, and thus the impact of foreigners on suburbanisation. In search of geographical similarities, this section ends by a cluster typology classifying Spanish urban areas with similar patterns. The second analytical section studies the impact of recession in the aforementioned processes. Significant results indicate that, as a consequence of the economic crisis, Spanish metropolis would seemingly be entering in a new lower growth and mitigated 
suburbanisation phase. Yet, several nuances, discussed in the final conclusions, should also be taken into consideration.

\section{Theoretical framework, concepts and data}

The stages of urban development and the impact of migration flows

The classical cyclical urbanisation model or 'stages of urban development' built by Van den Berg et al. (1982) has widely been used by many urban geographers and other urban researchers with the intention to explain past and present population changes in functional urban regions (FUR) and to compare contemporary European urban trends (Cheshire and Hay, 1989; Lever, 1993; Cheshire, 1995; Champion, 1995; Haase et al., 2005; Buzar et al., 2007; Turok and Mikhnenko, 2007; Kabisch and Haase, 2011). This model is useful as it does not merely analyse urban demographic developments as a whole, but focuses on both urban core and surrounding fringe area trends. More specifically, it describes urban growth and decline periods in Europe through four sequential stages: urbanisation, suburbanisation, desurbanisation and reurbanisation, each one being sub-divided into two periods of relative or absolute population increase (centralisation) or decrease (decentralisation).

At a first stage, urbanisation, the core city gains more population than the surrounding region, while the opposite occurs in the following phase, suburbanisation, when 
demographic decentralisation leads to core city (first relative and then absolute) losses, while surrounding areas rapidly increase their inhabitant numbers. During the suburbanisation stage, all the urban area as a whole still shows positive growth, however, the sign shifts to negative in the subsequent phase, desurbanisation, when both core cities and fringe area populations decline. The latter start to present a negative demographic trend, while central cities become increasingly de-populated (Hall, 2006). In extreme cases, these can even fall into disrepair, decrepitude and vacancy -a phenomenon called 'urban decay' by some authors like Medhurst and Parry Lewis (1969) or Andersen (2003), and ‘shrinking cities' by others (Oswalt, 2003; Oswalt and Rieniets, 2006; Ebers, 2007). When population and economic activities in rural areas and satellite non-metropolitan towns grow along with desurbanisation, the phenomenon has been called ‘counterurbanisation’ (Fielding, 1982).

Finally, desurbanisation should be followed by a fourth and final stage, reurbanisation, which would complete and restart the urban development cycle and which is characterised by a progressive core city population recovery and a later fringe area decline rate reduction. Van den Berg et al. (1982) considered this fourth stage as a purely hypothetical and unlikely. Nevertheless, population data collected in the 1990s and the early $21^{\text {st }}$ century shows that many core cities are once again gaining population and thus, some sort of reurbanisation -even if is this concept is still under-theorised (Buzar et al., 2005) and therefore used with very different meanings (Rérat, 2012) ${ }^{1}$ - is 
in fact taking place (Lever, 1993; Cheshire, 1995; Ogden and Hall, 2000; Haase et al., 2005; Buzar et al., 2007; López-Gay, 2011).

Still, this core cities demographic recovery does not necessarily imply (as the reurbanisation stage of the Van den Berg et al. model suggested) that suburban peripheries have to lose population. In fact, most continue gaining it -and some even more than core cities. In other words, European cities which, before 2001, were seemingly approaching the desurbanisation stage, would apparently be once again returning to the suburbanisation one, without going through reurbanisation. This contradicts the strict and unavoidable sequential order described by 'stages of urban development' model (Kabisch and Haase, 2011). ${ }^{2}$ This is however not the only criticism the model has received. The present coexistence in Europe of metropolitan areas which are (re)urbanising with others which are at the suburbanisation stage or the desurbanisation one (Buzar et al., 2007; Kabisch and Haase, 2011), confirms that there is not just one single trajectory for European urban areas, but different ones depending on development patterns and country characteristics (Champion, 1995; Cheshire, 1995).

Other critics focus on the way the functional urban region (FUR), its two components core cities and fringe areas-, and relations between them, have been defined in the model. For example, Antrop (2004) disapproves of core city definition on the basis of administrative limits, as they provoke comparability problems and do not reflect the changing spatial structure of a city. Hugo et al. (2003) on their side do not agree on 
basing fringe area delimitation on commuting zones between the core city and its suburbs. Other authors also emphasise that, in the model, the latter are defined as homogeneous whereas they are often very heterogeneous (Rérat, 2012).

As for FUR definition, the classic cyclical urbanization model is based on fix FUR limits, as if it were a closed system where core cities grow again to the detriment of their suburbs. This contradicts a reality marked by continued urban sprawl and counterurbanisation, and with very few signs of suburb decline (Champion, 2001a; Storper and Manville, 2006). Additionally, FUR fixed limits introduce scale problems, as inner suburb population diminutions can be interpreted as desurbanisation while municipalities not yet included in the FUR (outer suburbs) can really still be growing. In other words, suburbanisation would be still continuing but at a larger scale (Bretagnolle et al., 2002). Finally, considering the urban area as a closed system emphasises internal migratory movements between core cities and fringe areas, ${ }^{3}$ undermining the relevance of external migrations from the rest of the country or abroad.

Yet, the urban recovery phase observed in many European urban areas in the early $21^{\text {st }}$ century is seemingly caused by the settlement of two parallel but different flows in core cities, one made up of nationals and the other of foreigners.

The settlement of nationals would mainly be related to household structure and lifestyle changes linked to the so called ‘second demographic transition'. Among other changes, this process would imply less and later marriages, more consensual unions, divorces and 
couple breakups, and therefore, more one-person and single-parent households, more non-family households and other non-traditional ones (Van de Kaa, 1987; Lesthaeghe and Neels, 2002). These new family forms tend to settled in the urban centres, as young adults seeking better educational and work opportunities, or those just attracted by cities due to their positional advantages and way of life, also do (Champion, 2001b; Buzar et al., 2005; Kabisch and Haase, 2011; López-Gay, 2011). The same can be stated for other groups like non-autonomous elderly people, and new middle classes or 'gentrifiers' (both nationals and foreigners), increasingly attracted by core cities. Though the size of these new types of household are, on average, relatively small, what makes them particularly important for city centres is that they are becoming a growing inflow. Families with children, on the contrary, still present negative, though decreasing, migration rates (Rérat, 2012).

In the case of Spanish cities, as Vinuesa (2005) or López Gay (2011) underline, the settlement of new household types has been favoured by population ageing in city centres, which means that many dwellings became empty, therefore increasing housing supply for both nationals and foreigners.

Other second demographic transition changes have also influenced this increasing metropolitan centre-periphery differentiation, particularly visible in Madrid and Barcelona. On the one hand, their cores have both much lower total fertility rates (1.15 children per woman in Barcelona and 1.31 in Madrid) than their peripheries (1.53 and 
1.65, respectively). On the other, in both cities, births also take place later (Pujadas et al. 2012; Pozo and Rodríguez-Moya, 2003). In fact, due to fewer and later births, most large Spanish cities have negative natural growth rates (e.g. Barcelona, Bilbao) or, as in the case of Valencia and Madrid, very low positive ones (Bayona et al. 2011). These fertility differences have also been observed in France (Fagnani, 1991) or Northern Europe (Kulu and Boyle, 2009; Kulu et al., 2007 and 2009).

However, in some European countries the new phase of urban growth would not mainly be explained by second demographic transition changes, but by the arrival of labourrelated foreign immigrants. This last decade, these international flows, mainly from central and eastern Europe and other developing countries, ${ }^{4}$ have particularly been strong in Spain and other southern European countries with highly segregated labour markets (Domingo and Gil-Alonso, 2007) which offered plenty of mainly low-paid jobs to international labour migrants. Initially, they tend to settle in core cities -and particularly in their low-quality neighbourhoods (Bayona et al., 2011; Bayona and López-Gay, 2011)- as their central location offers them more work opportunities, better public transport, abundant and cheaper housing, and easier networking with other immigrants of the same ethnic group or nationality (Champion, 2001a; Buzar et al.; 2007; Bayona and Gil-Alonso, 2012a).

The 'stages of urban development' model, which does not explicitly take these international migrations into consideration, therefore poses problems to be considered 
as an adequate analytical framework to analyse Spain's early $21^{\text {st }}$ century urban processes. Notwithstanding, it can be regarded as a good conceptual starting point as it requires to analyse core city and periphery growth separately. Results obtained from the use of this framework have allowed us to classify Spanish urban areas according to the cyclical urbanisation stage at which they stand and to search spatial patterns through a cluster grouping agglomerations with similar core city and periphery growth patterns.

\section{Data and Urban Areas Definition}

The basic source is the Padrón continuo, the local continuous registration system providing official data updated on January the $1^{\text {st }}$ each year. It is annually collected and harmonised by the Spanish National Statistics Institute (INE) and it permits to obtain municipality level annual stock data on Spanish and foreign nationality inhabitants, thus allowing to yearly study both populations' settlement dynamics. The period analysed (2001-2011) has been divided into two phases: the first going from January the $1^{\text {st }} 2001$ to January the $1^{\text {st }} 2008$, corresponding to the economic growth and large immigration flow period, and the last, including only three years, from January the $1^{\text {st }} 2008$ to January the $1^{\text {st }} 2011$ (last available consolidated data when writing these lines), characterised by recession and slow foreign population increase. 1970, 1981 and 1991 Censuses have also been used to present previous decade urban population patterns. Finally, flow data on births and deaths from the INE's Movimiento Natural de la 
Población (MNP) have also been employed to calculate natural growth. Migratory growth for each of the geographical areas analysed is obtained by subtracting the latter from total growth.

The choice of the particular urban areas to be studied posed two main difficulties. On the one hand, there was the issue of where to situate the threshold from which a group of municipalities should or not be considered urban. On the other, there was also the issue of geographical limits. The lack and difficulty of obtaining harmonized data, due to the absence of homogeneous official definitions of Spanish metropolitan areas similar to MSA and CSA American ones- has led to the proposal of diverse delimitations: AUDES - Áreas Urbanas de España (http://alarcos.infcr.uclm.es/per/fruiz/audes/), Nel·lo (2004), Serrano (2007), Feria (2008, 2011), among others. As none have been officially adopted, for this particular study, we decided to employ the metropolitan area delimitation used in the Atlas de las Áreas Urbanas de $E^{E s p a n ̃ a}{ }^{5}$ (Ministerio de la Vivienda, 2006) and to situate the threshold at 500,000 inhabitants. In sum, fifteen metropolitan areas satisfied the requirements. Madrid is the only exception to the former definition and limits, as we consider that the Atlas delimitation of its metropolitan area is too restrictive. The whole Autonomous Community (administrative region) has been taken into account instead. ${ }^{6}$ Despite admitting the Atlas quite often uses administrative limits which do not always reflect 
population dynamics, employing it increases result comparability with other studies using the same administrative definitions.

Among the selected fifteen urban areas there are eleven which would fit the classical definition of a metropolitan area, i.e. a core city giving it name and its suburban periphery. The other four would have grown from two or three central points: Asturias central urban area (Gijón, Oviedo and Avilés being the main cities within it), Bahía de Cádiz (Jerez de la Frontera and Cádiz), Alicante-Elche and Vigo-Pontevedra. The number of municipalities composing these metropolitan areas ranges from four, in the case of Las Palmas de Gran Canaria, to 164 in the case of Barcelona and 178 in that of Madrid. In all, there are 564 municipalities (representing 7\% out of a present total of 8,114) holding nearly 22 million inhabitants, that is to say, $46.6 \%$ of the Spanish population in 2011.

\section{Results (I): Urban population growth patterns}

The impact of international migration

This last decade has seen a significant growth in the main metropolitan area figures. The 19,055,248 residents of the year 2001, became 21,986,679 ten years later (see table 1). These three million more dwellers represent more than half of all the decade's population increase for Spain as a whole, the annual cumulative growth rate for all the metropolitan areas being $1.44 \%$ (1.34\% for the rest of Spain). However, not all the 
urban areas have behaved the same way. The highest increase has been observed in Mediterranean coast urban areas like Murcia (2.17\%), Palma de Mallorca (2.04\%), Malaga (2.20\%) or Alicante-Elche (2.01\%). Madrid's metropolitan area growth rate is also significant (1.91\%). These provinces' quick population growth is basically explained by their general economic dynamism and particularly by their construction boom -which lasted from the mid 1990s to 2007. Indeed, while Madrid is Spain’s political and economic (in terms of GDP) capital and its main metropolitan area, the Mediterranean provinces have a highly diversified economy which includes intensive agriculture, industry and a developed tourist and other services sector. In fig. 1 (where the highlighted axes show Spain's mean values), all these urban areas appear within the NE quadrant, meaning that the areas growing more between 2001 and 2011 are also those receiving more foreign immigrants -a combination of Western European residential migrants and rest-of-the-world labour migrants. Indeed, foreigners represent 20.8\% of Palma de Mallorca urban area 2011 population, 16.5\% of Madrid’s one, and Alicante-Elche, Malaga and Murcia show similar figures, all well above the $12.2 \%$ Spanish mean.

\section{FIGURE 1 ABOUT HERE}

Barcelona, Zaragoza and Valencia, as the former group, are also economically dynamic areas, which have received many migrants. However, their population has not grown as 
much. Therefore, they combine relatively high foreigner shares and slightly low population growths under the Spanish mean (SE sector).

The less dynamic metropolitan areas have, on the contrary, received little immigration (fig. 1 SW quadrant), the smallest annual increases being: 0.06\% for Bilbao; 0.33\% for Asturias central region; 0.60\% for Vigo-Pontevedra; 0.68\% for Las Palmas de Gran Canaria, 0.94\% for Bahía de Cadiz and 0.98\% for Seville. All these metropolitan areas are in fact also those which have the lowest percentages of foreigners, the extreme values being found in Seville (4.6\%) and Bahía de Cadiz (2.8\%). All these urban areas are either situated on the Atlantic coast (northern, north-western and south-western Spain) or slightly further inland -in the case of Seville- and have been less affected by the real estate bubble. As their economic growth has been smaller they have received less foreign immigrants and their population has grown less than the Spanish mean. Granada would be the only exception to this group. Despite having relatively low alien percentages, that is to say, under the Spanish mean, population has grown more than the country as a whole. As it can be observed (fig. 1), it is the only case situated in the NW quadrant.

In sum, foreigners' presence in Spain's main urban regions is highly irregular, the proportion of immigrants living, in 2011, in seven of the fifteen areas dropping significantly under the Spanish mean. 2001-2011 urban growth rates are subsequently 
very uneven. The picture becomes even more complex when the distinction between core cities and peripheries is introduced.

\section{TABLE 1 ABOUT HERE}

Spatial distribution of growth: Urban cores and fringe areas

Demographic relevance of each of the 15 central cities respect their own metropolitan region differs considerably. While, in 2011, the city of Barcelona contained only 32.1\% of the whole urban area residents, Zaragoza held $90.7 \%$ of them. In between a whole number of intermediate situations can be found (fig. 2).

FIGURE 2 ABOUT HERE

Two elements play a crucial role in these differences, the number of municipalities composing each of the urban areas and the central city's size -in spatial terms-, the latter ranging from $12 \mathrm{~km}^{2}$ in Cadiz to $1.188 \mathrm{~km}^{2}$ in Jerez de la Frontera and $1.063 \mathrm{~km}^{2}$ in Zaragoza. Globally speaking, however, during this decade, most of the urban areas have followed two common trends: population growth and urban decentralisation and expansion. As it can be observed in fig. 3, in 12 out of the 15 cases, both core cities and fringe areas have grown, and the latter more so than the former. 


\section{FIGURE 3 ABOUT HERE}

The three exceptions to this pattern would be the metropolitan areas of Granada and Bilbao, where the cores actually lost population, and the central urban area of Asturias, where the periphery diminished while its three central cities grew. In sum, except for the latter case, which would still be at the urbanisation stage with absolute centralisation (Van den Berg et al., 1982), the rest would be at a suburbanisation phase, and more specifically in the absolute decentralisation stage in the case of Bilbao and Granada, and in the relative one in that of the rest of metropolitan areas. Granada -together with Malaga, where the people living in the core city fell from 70\% in 2001 to $60 \%$ in 2011 would be the most paradigmatic deconcentration case, as its core city inhabitants dropped from $56 \%$ of the total urban area population in 2001 to only $46 \%$ in 2011 . In other words, its residents annually diminished by $0.13 \%$ while periphery ones grew by 3.68\%. Bilbao would be a slightly different case as its population distribution almost remained stagnant, its central municipality yearly decreasing by $0.04 \%$ and its periphery increasing by only $0.12 \%$.

This last decade’s eccentric behaviour of Asturias, Bilbao and Granada, can be better observed in fig. 4 showing the 15 metropolitan areas' 2001-2011 annual growth rates for both core cities and fringe areas and thus allowing to make comparisons with those of the previous three decades. Last decade's growth trends are similar to those of the 
1970s, when both urban cores and suburbs augmented considerably their population size -though Madrid and Barcelona, the main cities, already showed a practically stagnant population as their suburbanisation had already started in the 1960s.

The 80s and the 90s show a different picture. While increasingly more core cities lost population, peripheries continued to gain it, although at a decreasing pace. From the year 2001 onwards, the main metropolitan areas seem to demographically relive due to international immigration (see foreigner annual growth rates and their increasing population share in table 1). These flows have strengthened both core city and fringe area positive migratory growth. ${ }^{7}$ The only exceptions would be the cities of Seville and Granada, which are still losing population due to emigration -foreigner arrival does not compensate for Spaniards' exit flows towards the suburbs. Although in the former case, positive natural increases counterbalance migrant loss, in that of Granada this is not so, as it is the only core city significantly losing population in this last decade (fig. 4).

\section{FIGURE 4 ABOUT HERE}

Considering Spanish population on its own (see table 1), trends are quite different. In most of the metropolitan areas, the largest ones among them, fringe areas gain Spaniards -Zaragoza, Malaga, and Granada particularly intensely- while their core cities lose them. Within this group, Barcelona and Madrid would be especially noteworthy due to their relevance. Only six urban area cores (Murcia, Alicante-Elche, 
Jerez-Cadiz, Las Palmas, Vigo-Pontevedra and the three Asturian cities) gain local residents - even though not as much as their peripheries. Asturias is the only exception to this group as its cores gain Spaniards while its periphery even loses them. Finally, both the centre and the periphery of Bilbao lose nationals.

Regarding foreigners' absolute figures and shares since the year 2001, they have not cessed to increase in all centres and fringe areas. Nevertheless, their settlement trends are somewhat obscure and irregular. While in some urban areas they are more attracted by the periphery, in others they seem to prefer the centre. In 2011, Malaga's periphery presents the highest proportion of foreigners (27.6\%) of all, followed by Palma de Mallorca (21.8\%), while Central Asturias’ fringe area has the lowest one (3.1\%). On the other hand, Palma de Mallorca (20.5\%), Barcelona (17.2\%) and Madrid (17.0\%) show the highest core city foreigner shares, and the two Bahía de Cadiz centres, the lowest $(2.4 \%)$

In sum, even though urban centres have gained population (an annual mean of $0.79 \%$ between 2001 and 2011), suburban municipalities show the highest increases (2.18\%). Therefore, in relative terms, cores have lost importance. In 2011, the percentage of people living in central cities was a 3.4\% points less than ten years before, decreasing from $54.9 \%$ to $51.5 \%$. This is both due to differences in migratory growth (15.3 per thousand in fringe areas compared to 6.0 per thousand in core cities) and in natural growth (peripheries’ 5.5 per thousand compared to 1.4 per thousand in core cities). 
Young Spanish families' suburban settlement preferences are the main drivers of these trends -they search larger higher quality housing at lower (per square meter) prices, in less dense and noisy areas which are nearer to nature. Foreigners are also increasingly involved in suburbanisation and, despite preferably settling, at least in a first stage, in core cities, they have later reinforced Spaniards’ decentralisation dynamics (Bayona and Gil-Alonso, 2012a). In 2011, $12.4 \%$ of the suburban population is foreign, a very similar share to that found in core cities, i.e. $13.0 \%$.

Typology of main Spanish urban areas

Even though, this last decade, Spain's main metropolitan areas have grown and expanded, figures undoubtedly underline significant differences among them. Can spatial patterns be found? A series of indicators -total, natural and migratory growth, and share of foreign people (table 2)- has been used to classify the 15 metropolitan areas through cluster analysis. Four groups of areas which have similar characteristics have been obtained and they moreover show coherent geographical patterns.

Category 1 (Alicante-Elche, Barcelona, Madrid, Murcia, Palma de Mallorca and Valencia) contains the most demographically dynamic urban areas. Even though they are all undergoing strong suburbanisation processes, their metropolitan cores are still considerably increasing. Both the periphery and core cities have substantial amounts of 
foreigners and therefore show significant natural (with the exception of the city of Barcelona) and migratory growth.

Category 2 metropolitan areas (Malaga and Zaragoza) show similar patterns to those of the previous category, though the growth of their centres is lower and that of fringe areas is much higher. In other words, both metropolitan areas have undergone an extremely strong suburbanisation process. As a result, their rapidly increasing peripheries have a particularly young population structure with high migratory and natural growth.

Category 3 metropolitan areas (Bahía de Cadiz, Granada, Las Palmas de Gran Canaria, Sevilla, and Vigo-Pontevedra) have low foreign population shares both in core cities and fringe areas. These are indeed well below the Spanish mean, and those of the periphery, particularly so. It is the only category in which core city natural growth is higher than migratory one. However, each metropolitan area contains its specificities. Bahía de Cadiz and Seville are two south-western metropolitan areas showing, like Vigo-Pontevedra, in north-western Spain, low foreign migration figures. Yet, the case of Las Palmas (in Canary Islands) requires some additional explanations. The large amounts of foreigners living in the island prefer to settle in the tourist south of Gran Canaria rather than in the main city, in the north of the island. Granada is another different case as, during the analysed decade, its core shows a highly negative migratory growth which is not compensated by a tiny positive natural increase. Its periphery 
follows the opposite trend, as it has very significant Spanish immigration flows and one of the highest natural growth rates.

Category 4 urban areas (Bilbao and central urban area of Asturias, both in northern Spain) have a stagnant population both in the cores and in the peripheries. Foreign immigration to them is relatively low and their suburbanisation flows are the lowest of all. In fact, Gijon, Avilés and Oviedo, the three Asturias’ core cities, are still gaining population while their industrial and mining fringe areas lose it. On the other hand, Bilbao's metropolitan area population is very stable. While it is slightly diminishing in the centre, it hardly grows in the periphery. Natural growth in these core cities is clearly negative and in Asturias’ fringe area, extremely so.

\section{TABLE 2 ABOUT HERE}

In sum, Mediterranean urban areas and Madrid and Zaragoza interior ones (categories 1 and 2) have had high population increases, strong suburbanisation processes and large foreign immigration flows. The rest -in northern, north-western and south-western Spain-, have experienced much lower foreign immigration levels, and thus, lower growth and suburbanisation processes. Geographical patterns are therefore clearly visible, at least until 2008, when recession breaks out. 


\section{Results (II): The impact of the economic crisis on urban growth (2008-2011)}

As stated, the 2001-2011 decade has been divided into a first economic expansion period (from 1 January 2001 to 1 January 2008) and a second recession one (from 1 January 2008 to 1 January 2011). Obviously, there has been higher demographic growth in the former than in the latter interval, annually respectively increasing by $1.71 \%$ and 0.82\% (table 1). Despite rising more rapidly than nationals these last three years, foreigners have grown nine times less than what they previously did. In other words, recession has hardly stricken immigrant entry flows. Oddly enough, however, Spanish citizen annual growth rates indicate that their metropolitan area figures have been increasing more after than before $1 / 1 / 2008$ (from an annual $0.38 \%$ to a $0.60 \%$ ). Rather than by natural or migratory growth, this trend could be explained by naturalisations (Bayona et al., 2011). ${ }^{8}$

As for more precise metropolitan area developments, none of the 15 areas studied lost absolute population after 2008, though after that date gains were smaller. Nevertheless, for a proper comparison, annual cumulative growth rates should be introduced. Under this new perspective, one of the urban areas -Bilbao- grew more in the crisis period than it did in the expansion one. Between 2008 and 2011, Bilbao's previously stagnant population increased by a small $0.15 \%$. The rest of urban areas reduced their growth rates during the crisis, though at diverse scales. The areas which had grown less during 
the economic expansion period (Asturias, Granada, Seville, and Vigo-Pontevedra, that is to say, those pertaining to categories 3 and 4) have hardly reduced their rates, whereas those metropolitan areas which grew more in the previous period (categories 1 and 2) have seen the opposite trend and have therefore considerably fallen in the last three years.

Fig. 5 allows differentiating total, national and foreign population core city and fringe area annual growth rates in both periods. Between 2001 and 2008, all core cities, except for those of Granada, Bilbao and Seville, grew. However, all the peripheries -except for that of the metropolis of Asturias, which had negative rates- increased even more, being the cases of Zaragoza and Malaga, particularly significant. This generalised urban centre expansion period cannot be understood without the huge foreign immigration inflows they received, as 8 of the core cities actually lost Spanish population. The cases of Granada (-1.04\% annually) and Barcelona (-0.92\% annually) would especially stand out. On the opposite side, all peripheries but those of the central area of Asturias (0.54\%) and Bilbao (-0.39\%) gained Spanish residents.

Interestingly enough, the 2008-2011 crisis seems to have particularly affected peripheries and those centres which grew more during the previous period, i.e. those that received more foreign immigrants. By contrast, core cities gaining fewer foreigners during expansive years are also those less modified by the crisis. Cities like Seville and Granada have even changed negative growth rates for small positive ones. 


\section{FIGURE 5 ABOUT HERE}

Spaniards' growth rates seem to be less affected by the crisis. The number of urban centres losing local nationality citizens even reduces from 8 to 5 (figure 5). The cities of Granada, Madrid, Palma de Mallorca, and Zaragoza have stopped losing Spaniards and are gaining autochthonous population since 2008. Malaga, however, now loses it. In Barcelona, Valencia, Seville and Bilbao, on their side, Spanish residents diminish in both periods, though less in the second. Regarding fringe areas, all but two, Asturias and Bilbao, still augment their Spanish population, though generally at a slower pace. Therefore, recession has had two main consequences on Spanish urban areas: it has critically reduced the entry of foreigners and significantly slowed suburbanisation down.

\section{Discussion and conclusions}

In the early $21^{\text {st }}$ century, all the Spanish metropolitan areas with more than half a million residents have gained population. And not only fringe areas have -like in the four former decades- but (and that is a novelty) core cities too. This demographic recovery has also been observed by Kabisch and Haase (2011) in other southern European cities since 2001. However, though (re)urbanisation processes are generally increasingly significant in southern Europe, suburbanisation is still predominant, as 
many fringe areas gain more population than their cores. On its side, desurbanisation is currently hardly present. All these common trends can also be observed in Spain. Bilbao and central Asturias metropolitan areas would be the only ones respectively experiencing desurbanisation and (re)urbanisation, while all the rest would be in the suburbanisation stage -either in the absolute or relative decentralisation phase. These results for Spain seem to confirm Kabisch and Haase (2011) and other authors arguments, that the Van den Berg et al. (1982) urbanisation stages would not follow one another in a cyclical way but would be simultaneous. Therefore, at one precise moment in time, different cities would be at diverse stages depending on their morphology, size and the economic activities developed in them.

Independently from the urbanisation stage, current European urban area core city growth is mainly due to the arrival of young people and households, a change associated to the second demographic transition. This process implies that families are becoming smaller and more fragile, and there are increasingly more one-person and single-parent households, while young families still mainly tend to move to suburbs (Kabisch and Haase, 2011; Rérat, 2012). Nevertheless, the Spanish case would be somewhat different to that observed in other countries as it would not follow the usual recentralisation model where native people return to the urban centre (Cheshire, 1995; Champion, 2001a). Here, those moving into metropolitan cores are no longer mainly Spanish people. In fact, in most cities, their stocks would actually be smaller than in 2001 due to 
net emigration from urban centres, though López-Gay (2011) beliefs that this trend is slowing down and may change sign in the near future. Those settling in cores would rather be foreign immigrants (see Bayona and Gil-Alonso, 2012a; and Pujadas, 2009, for Barcelona; or Pozo and García, 2009, for Madrid) who arrived during the Spain’s immigration boom. In other words, if it had not been for foreigner settlement, all Spanish core cities but two (Murcia and Alicante-Elche) would have had stagnant or regressive populations due to the diminution of Spanish stocks.

Moreover, considering metropolitan areas as a whole, growth would have been much lower without immigrants -and even negative in the case of Bilbao and Asturias urban areas. Therefore, in the Spanish case, there is a direct relationship between international immigration and urban growth. With few exceptions, the more foreign migrants has an urban area received, the more its population has increased, so growth magnitudes have been extremely different. Bilbao metropolitan area and the Comunidad de Madrid would be the paradigmatic extreme cases. While in former population remained nearly stagnant, that of the Comunidad de Madrid, augmented in more than 1.1 million inhabitants. Generally speaking, in the 2001-2011 period, south-western, north-western and northern urban areas received few immigrants and therefore show small population increases, while Mediterranean urban areas, Madrid and Zaragoza followed the opposite trend, and strongly increased fuelled by the arrival of foreign immigrants. 
How can this divergent demographic behaviour between both groups be explained? A different economic structure and changes in employment dynamics during this last decade would seem to be the main explanation. The first group of cities -those belonging to category 3 and 4- hardly had a real estate boom and their economy was not very dynamic before 2008. Therefore, they received little immigration during that period. Additionally, the economy of these areas (particularly those of the north and north-eastern Spain) is based on the industrial sector and has a less developed construction, tourism and services sector. Consequently, the crisis did not strike them as hard as Madrid or the Mediterranean provinces (categories 1 and 2), which have been particularly affected by the collapse of the construction and real estate sector (VidalCoso et al., 2012). Therefore, the first group has been less concerned by the reduction of immigrant flows due to the economic crisis and their foreigner figures are currently presenting the highest growth rates, either because their stocks were very low and therefore now rise relatively fast (the case of Sevilla and the Bahía de Cadiz) or because foreigners are currently moving from those areas which have been most hardly hit by the crisis (the Mediterranean coast) to the northern industrial urban areas like Bilbao or Asturias (Bayona and Gil-Alonso, 2012b).

Generally speaking, the 2008 economic and real estate crisis seems to have slowed Spanish metropolitan area growth down and restrained suburbanisation dynamics. The 
two reasons behind this trend change would be that fewer immigrants are entering and less Spaniards are changing their place of residence.

On the one hand, as many less foreigners arrive, metropolitan areas have reduced the pace at which their cores and peripheries enlarge. Indeed, until recession, immigrants firstly settled down in core cities -where they rented or bought flats to Spanish people, therefore facilitating their migration to peripheries- and then, increasingly, in suburban municipalities. As these last three years foreigners are moving much less towards them, they have considerably diminished their growth rates.

On the other hand, as getting access to new dwellings has presently become much more difficult -due to the economic, financial and particularly the housing market crisis, which has led to the construction sector collapse while access to mortgage loans has heavily been restricted-, Spaniards are moving less and exit flows from core cities to suburbs have been reduced. Therefore, with few exceptions, urban centres are currently once again gaining Spanish residents or at least have stopped losing them.

\section{Funding}

We would like to acknowledge the Spanish Ministry of Science and Innovation for funding the CSO2011-24680 R+D Project through the 2008 -2011 National R+D+i Plan, and for funding Dr. Gil-Alonso through the Ramón y Cajal programme, which is cofinanced by the European Social Fund. 


\section{Notes}

${ }^{1}$ Rérat (2012) mentions at least four different definitions: as a new period of demographic growth of cities after a period of decline; as a stage of population decline of the suburbs together with either reduced loss or a new population growth of the core city (final phase of the Van den Berg et al. 'stage of urban development' model definition); as a process of (re)populating and diversifying the inner city with a variety of residential strata (Buzar, Ogden et al., 2007); and, finally, as a synonym of renewal or regeneration (gentrification) of core cities.

${ }^{2}$ See for instance the case of Spain, according to Nel·lo (2007): After a first concentration (urbanisation) period (1959-75), there was a strong dispersion or suburbanisation stage (1975-96) during which the main cities lost population. From this latter date onwards, Spanish cities entered a third phase which would not be desurbanisation, but further suburbanisation combined with urban centre recovery. This third phase concludes when the economic crisis irrupts, deeply striking both centre and periphery real estate markets.

${ }^{3}$ Moreover, these internal flows are considered as a whole, without taking internal migratory trend divergences into account (Ford and Champion, 2000). The volume, average size and other characteristics of migrant households are also frequently ignored, (Rérat, 2012).

${ }^{4}$ Simultaneously, numerous expats from North America and Western Europe have also been attracted by white-collar jobs in Madrid, Barcelona and other large South European cities, where they have mainly settled in medium-to-high-class neighbourhoods.

${ }^{5}$ Its definition of 'urban area' is based on population threshold criteria (a main nucleus of at least 50,000 inhabitants in 2006 Padrón Continuo, and surrounding municipalities which had more than 1,000 inhabitants that year) while their geographical boundaries are based on 2001 Census data (including housing, labour mobility, and activity sector data among others). Transport and communication networks, and land uses are also taken into account. 
${ }^{6}$ Some authors like Pozo and García (2009) even consider that the Madrid metropolitan area has actually overgrown the Autonomous Community boundaries.

${ }^{7}$ Foreigners' inflow has not only produced positive migratory growth, but has also allowed urban area natural growth -births minus deaths- to recover. The arrival of these large amounts of immigrants would have had two effects: on the one hand births would have risen and, on the other, it would have slowed ageing down. Therefore, all but three (Barcelona, Bilbao and Asturias) core city and fringe area natural growth rates have become positive. As for Barcelona and Bilbao, their core city natural growth is negative, while both the centre and periphery of Asturias lose population by natural growth.

${ }^{8}$ Indeed, acquisitions of Spanish nationally have grown from 21,805 in 2002 to 84,170 in 2008 and 123,721 in 2010. They are mainly Latin-Americans who can become Spanish citizens alter legally living in Spain for two years. They usually reside in urban areas as they often work in the services sector.

\section{References}

Andersen HS (2003) Urban sores: on the interaction between segregation, urban decay, and deprived neighbourhoods. Farnham: Ashgate.

Antrop M (2004) Landscape changes and the urbanization process in Europe. Landscape and Urban Planning 67: 9-26.

Bayona J and Gil-Alonso F (2012a) Suburbanisation and international immigration: The case of the Barcelona Metropolitan Region (1998-2009). Tijdschrift voor Economische en Sociale Geografie 103(3): 312-329.

Bayona J. and Gil-Alonso F (2012b) Europeans in Spain: Are their international and internal migration patterns affected by economic downturn?. EAPS European 
Population Conference 2012 'Gender, Policies and Population', Stockholm, 1316 June.

Bayona J, Gil-Alonso F and Pujadas I (2011) Dinàmica residencial de la població estrangera en les principals regions metropolitanes d’Espanya. Revista Catalana de Sociologia 27: 15-32.

Bayona J and López-Gay A (2011) Concentración, segregación y movilidad residencial de los extranjeros en Barcelona. Documents d'Anàlisi Geogràfica 57(3), 381-412.

Bretagnolle A, Paulus F and Pumain D (2002) Time and space scales for measuring urban growth. Cybergeo 219.

Bonvalet C and Lelièvre E (1997) The transformation of housing and household structures in France and Great-Britain. International Journal of Population Geography 3: 183-201.

Buzar S, Ogden PE and Hall R (2005) Households matter: the quiet demography of urban transformation. Progress in Human Geography 29: 413-436.

Buzar S, Ogden PE, Hall R, Haase A, Kabisch S and Steinführer A (2007) Splintering urban populations: Emergent landscapes of reurbanisation in four European cities. Urban Studies 44(4): 651-677.

Champion T (1995) Internal migration, counterurbanisation and changing population distribution. In: Hall R, White P (eds) Europe's Population Towards the Next Century. London: UCL Press, 99-129. 
Champion T (2001a) Urbanization, Suburbanization, Counterurbanization and Reurbanization. In: Paddison R, Lever WF (eds) Handbook of Urban Studies. London: Sage, 143-161.

Champion AG (2001b) A Changing Demographic Regime and Evolving Polycentric Urban Regions: Consequences for the Size, Composition and Distribution of City Populations. Urban Studies 38(4): 657-677.

Cheshire PC (1995) A New Phase of Urban Development in Western Europe? The Evidence for the 1980s. Urban Studies, 32(7): 1045-1063.

Cheshire PC and Hay DG (1989) Urban problems in Western Europe - An economic analysis. London: Unwin Heyman.

Domingo A and Gil-Alonso F (2007) Immigration and Changing Labour Force Structure in the Southern European Union. Population (English edition), 62(4): 709-727.

Ebers M (2007) Shrinking cities, the hidden challenge. Norderstedt: Grin Verlag.

Fagnani J (1991) Fertility in France: The influence of urbanization. In: Bähr J and Gans, P (Eds) The Geographical approach to fertility. Kieler Geographische Schriften 78: 165-173. Kiel: Geographisches Institut der Universität Kiel.

Feria JM (2008) Un ensayo metodológico de definición de las áreas metropolitanas españolas a partir de la variable residencia-trabajo. Revista Investigaciones Geográficas, 46: 49-68. 
Feria JM (2011) Ciudad y Territorio. Nuevas dinámicas espaciales. In: Pujadas I et al. (ed.) Población y Espacios Urbanos. Barcelona: Departament de Geografía Humana de la UB and Grupo de Población de la AGE, 13-52.

Fielding AJ (1982) Counterurbanisation in Western Europe. Progress in Planning 17: $1-52$.

Ford $\mathrm{T}$ and Champion $\mathrm{T}$ (2000) Who moves into, out of and within London? An analysis based on the 1991 census 2\% sample of anonymised records. Area 32: 259-270.

Frey W and Kobrin F (1982) Changing families and changing mobility: their impact on the central city. Demography 19 (3): 261-277.

Gil-Alonso F, Bayona J and Vono de Vilhena D (2012) Las migraciones internas de los latinoamericanos en España: del boom a la crisis económica. Papeles de Población 18(71): 9-50.

Haase A, Kabisch S and Steinführer A (2005) Reurbanisation of inner-city areas in European cities: Scrutinizing a concept of urban development with reference to demographic and household change. In: Sagan I, Smith DM (eds) Society, Economy, Environment - Towards the Sustainable City, Gdansk and Poznan: Bogucki Wydawnictwo Naukowe, 75-91.

Hall P (2006) Aged industrial countries. In: Oswalt P, Rieniets T. (eds) Atlas of Shrinking Cities, Ostfildern: Hatje Cantz, 144-145. 
Hugo G, Champion T and Lattes A (2003) Towards a new conceptualization of settlements for demography. Population and Development Review 29: 277-297.

Izquierdo A and López de Lera D (2003) El rastro demográfico de la inmigración en España: 1996-2002. Papeles de Economía Española 98: 68-93.

Kabisch N and Haase D (2011) Diversifying European Agglomerations: Evidence of Urban Population Trends for the 21st Century. Population, Space and Place 17: 236-253.

Kulu H and Boyle P (2009) High Fertility in City Suburbs: Compositional or Contextual Effects?. European Journal of Population, 25: 157-174.

Kulu H, Vikat A and Andersson G (2007) Settlement size and fertility in the Nordic countries. Population Studies 61(3): 265-285.

Kulu H, Boyle, P and Andersson G (2009) High suburban fertility: Evidence from four Northern European countries. Demographic Research, 21(31): 915-944.

Lesthaeghe R and Neels K (2002) From the First to the Second Demographic Transition: An interpretation of the Spatial Continuity of Demographic Innovation in France, Belgium and Switzerland. European Journal of Population, 18(4): 325360.

Lever WF (1993) Reurbanisation-The policy implications. Urban Studies 30(2): 267284. 
López-Gay A (2011) ¿Vuelve el centro? Caracterización demográfica de los procesos de reurbanización en las metrópolis españolas. In: Pujadas I. et al. (ed.) Población y Espacios urbanos, Barcelona: Departament de Geografia Humana de la Universitat de Barcelona and Grupo de Población de la AGE, 163-180.

López-Villanueva C and Pujadas I (2011) Transformaciones sociodemográficas y territoriales de los hogares unipersonales en España. Boletín de la Asociación de Geógrafos Españoles 55: 153-182.

Medhurst F and Parry Lewis J (1969) Urban decay: An analysis and a policy. London: Macmillan.

Ministerio de la Vivienda (2006) Atlas Estadístico de las Áreas urbanas en España. Madrid: Ministerio de la Vivienda.

Muñoz F and Izquierdo A (1989) L'Espagne, pays d'immigration. Population 44(2): 257-289.

Nel·lo O (2004) ¿Cambio de siglo, cambio de ciclo? Las grandes ciudades españolas en el umbral del siglo XXI. Ciudad y Territorio: Estudios Territoriales 36(141-142): 523-542.

Nel·lo O (2007) La tercera fase del proceso de metropolitanización en España. In: Artigues A et al. (eds.) Los procesos urbanos postfordistas. Palma de Mallorca: AGE and Universitat de les Illes Balears. 
Ogden PE and Hall R (2000) Households, reurbanisation and the rise of living alone in the principal French cities 1975-1990. Urban Studies 37(2): 367-390.

Oswalt P (2003) Shrinking Cities: International research. Ostfildern: Hatje Cantz.

Oswalt P and Rieniets T (eds) (2006) Atlas of Shrinking Cities. Ostfildern: Hatje Cantz.

Pozo E and García JC (2009) Inmigración y cambio demográfico en la región metropolitana madrileña entre 1996 y 2006. Anales de Geografía de la UCM 29(1): 111-138.

Pozo E and Rodríguez-Moya JM (2003) Diferencias socioespaciales en la fecundidad madrileña en el cambio de siglo. Estudios Geográficos, LXIV(252): 455-486.

Pujadas I (2009) Movilidad residencial y expansión urbana en la Región Metropolitana de Barcelona, 1982-2005. Scripta Nova. Revista Electrónica de Geografía y Ciencias sociales XIII(290) < http://www.ub.es/geocrit/sn/sn-290.htm > (accessed 27 July 2012).

Pujadas I, Bayona J, Gil-Alonso F and López-Villanueva C (2012) Diferenciación espacial en los comportamientos demográficos: el caso de la fecundidad en la Región Metropolitana de Barcelona (1986-2010). In: Reques P and De Cos O (ed.) La población en clave territorial. Procesos, estructuras y perspectivas de anàlisis. 145-154.

Reques P and De Cos O (2004) De lo global a lo local: repercusiones geodemográficas de la inmigración en España. Economistas 99: 48-61. 
Rérat P (2012) The New Demographic Growth of Cities: The case of Reurbanisation in Switzerland. Urban Studies 49(5): 1107-25.

Serrano JM (2007) Progresiva polarización demográfica de las aglomeraciones urbanas en España dentro de sus ámbitos provinciales. Geographicalia 51: 29-57.

Storper M and Manville M (2006) Behaviour, preferentes and cities: urban theory and urban resurgence. Urban Studies 43(8): 1247-1274.

Turok I and Mykhnenko V (2007) The trajectories of European Cities, 1960-2005. Cities 24: 165-182.

Van de Kaa DJ (1987) Europe’s second demographic transition. Population Bulletin 42(1): 1-59.

Van den Berg L, Drewett R, Klaasen LH, Rossi A and Vijverberg CHT (1982) Urban Europe: A Study of Growth and Decline. Oxford: Pergamon.

Vidal-Coso E, Gil-Alonso F and Domingo A (2012) La destrucción de empleo de migrantes y españoles (2007-2011): factores demográficos, sectoriales y territoriales (Employment destruction of migrants and Spaniards (2007-2011): Demographic, sectorial and spatial factors). VII Congreso Migraciones Internacionales en España. 'Movilidad Humana y Diversidad Social', Bilbao, 1113 April.

Vinuesa, J (2005) Dinámica demográfica, mercado de vivienda y territorio. Papeles de Economía Española, 104: 253-269. 


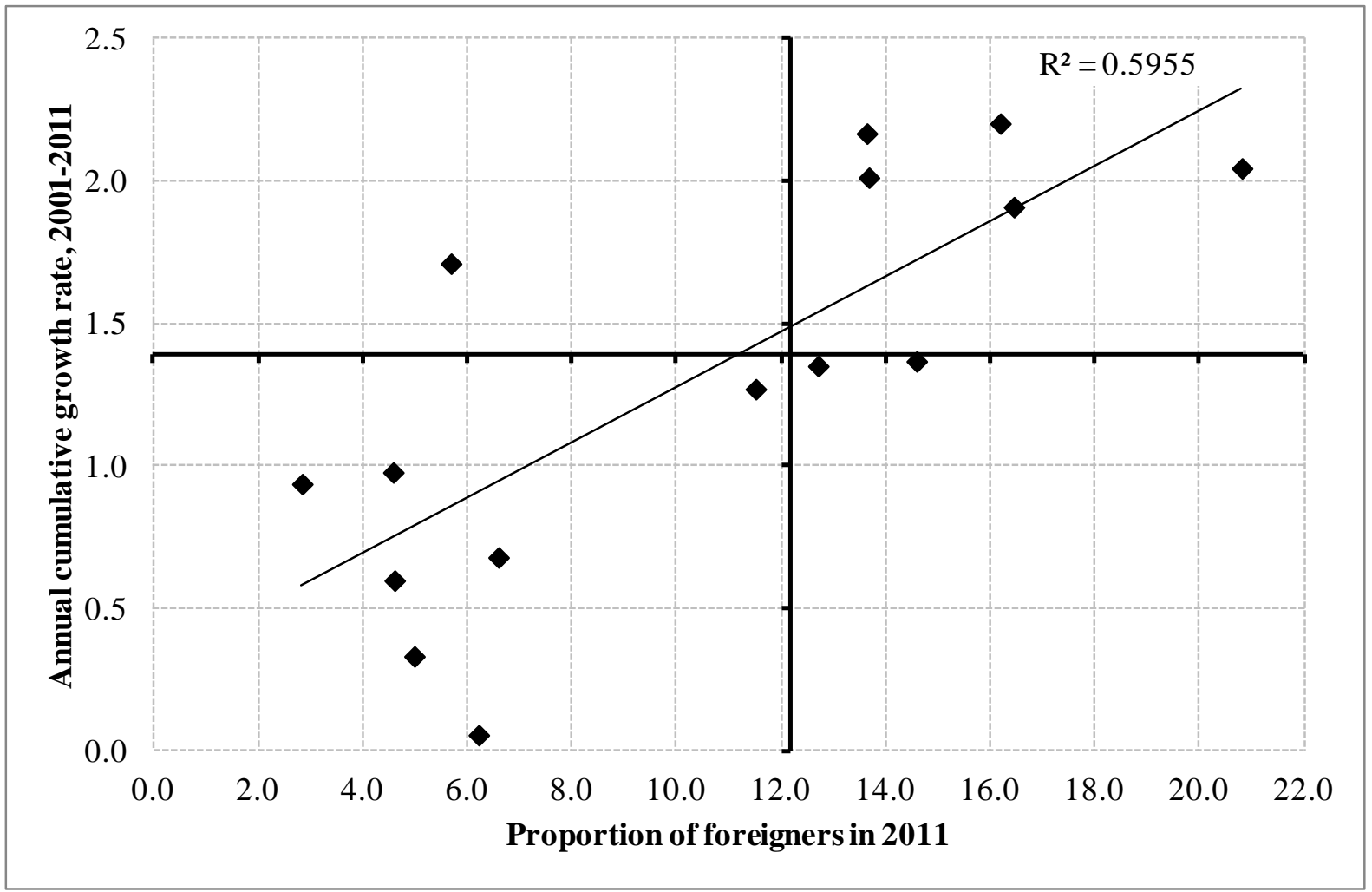

Figure1. Relationship between annual cumulative growth rates (r\%) and proportions of foreigners. Main Spanish metropolitan areas, 2001-2011.

Source: INE 2001 and 2011 Padrón continuo.

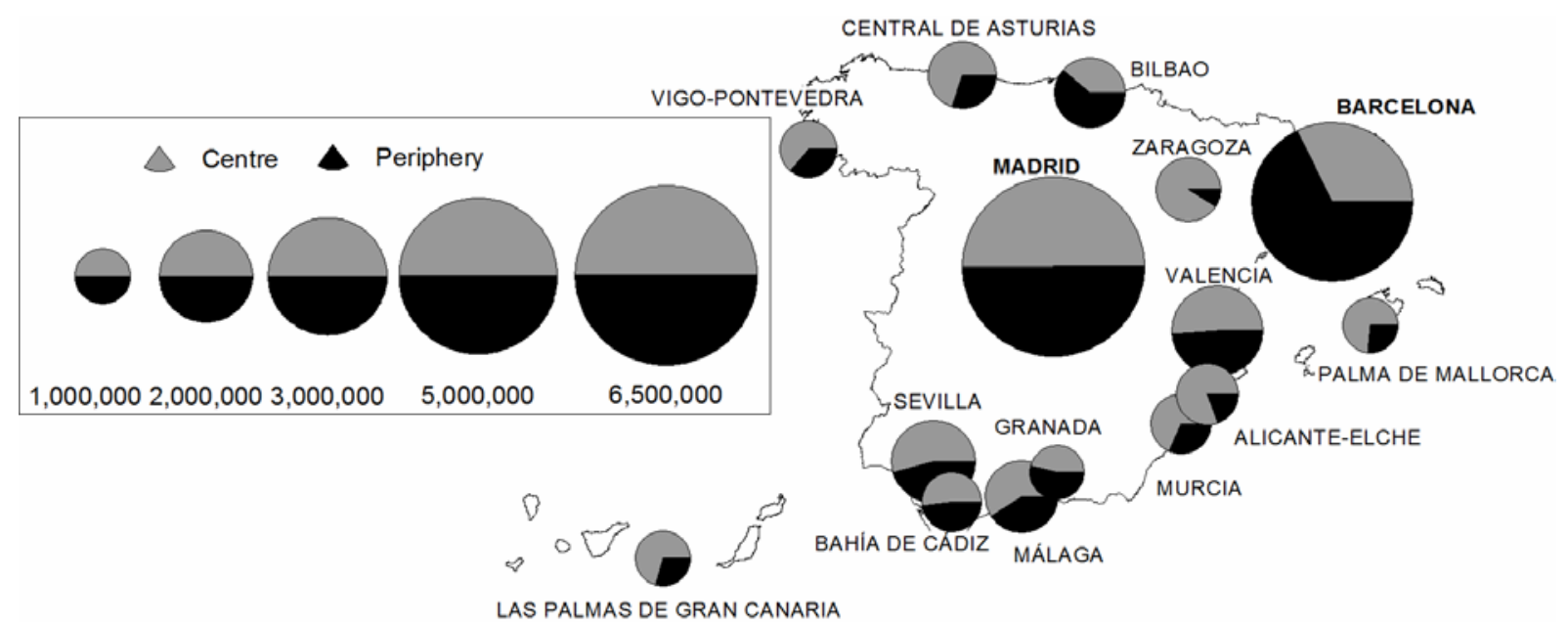

Figure 2. Centre-periphery distribution of population in the main Spanish metropolitan areas, 2011.

Source: INE 2011 Padrón continuo. 


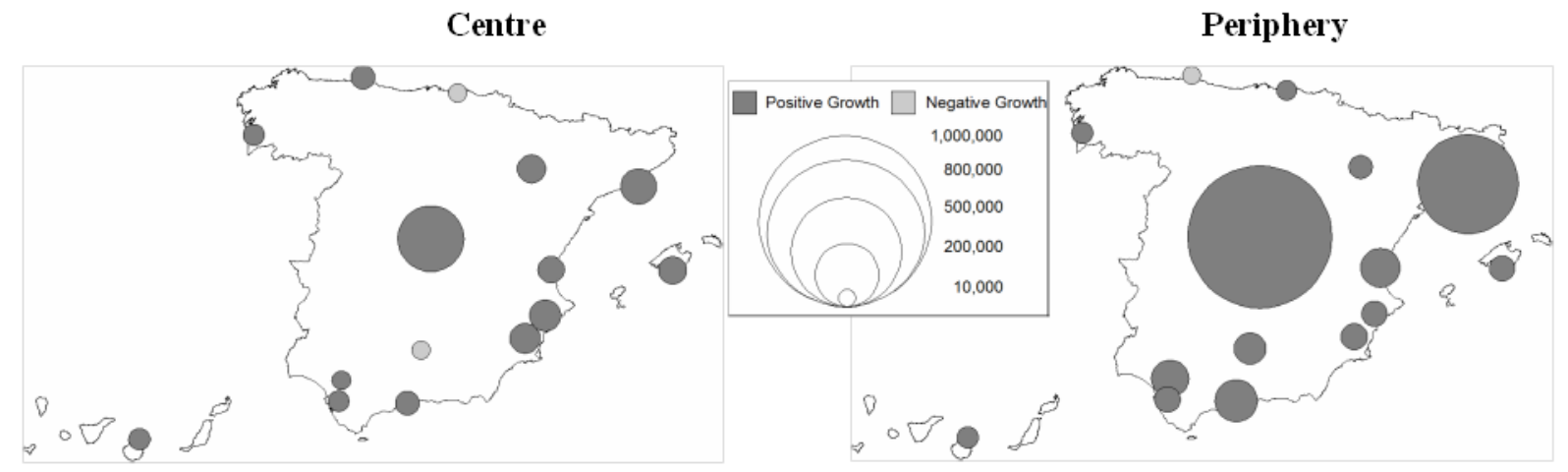

Figure 3. 2001-2011 core city and periphery metropolitan area absolute growth.

Source: INE 2001 and 2011 Padrón continuo. 


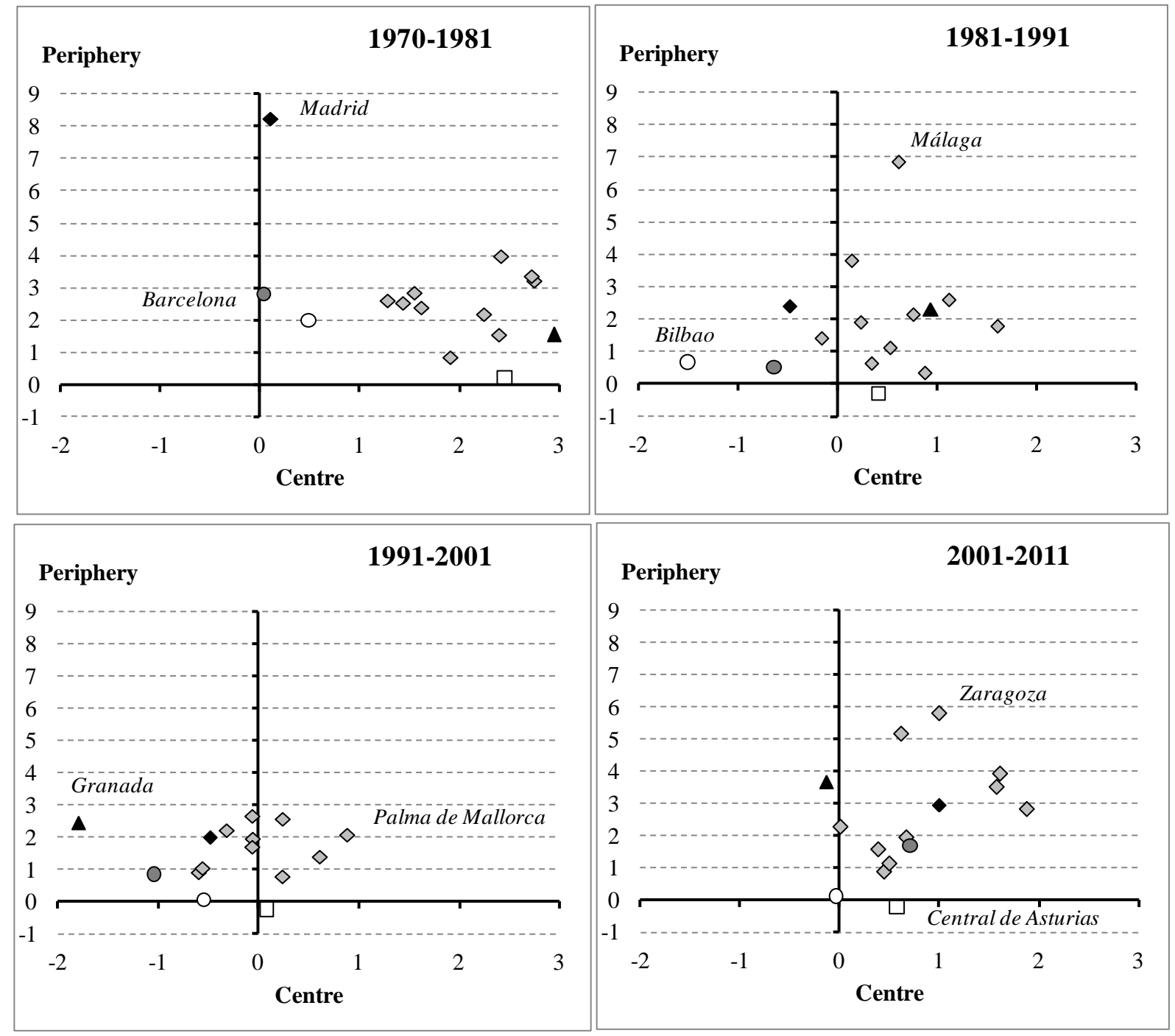

Figure 4. 10-year centre and periphery Spanish metropolitan area annual cumulative growth rates (r\%), 1970-2011.

Source: INE 1970, 1981 and 1991 Censuses and 2001 and 2011 Padrón continuo. 
TOTAL POPULATION

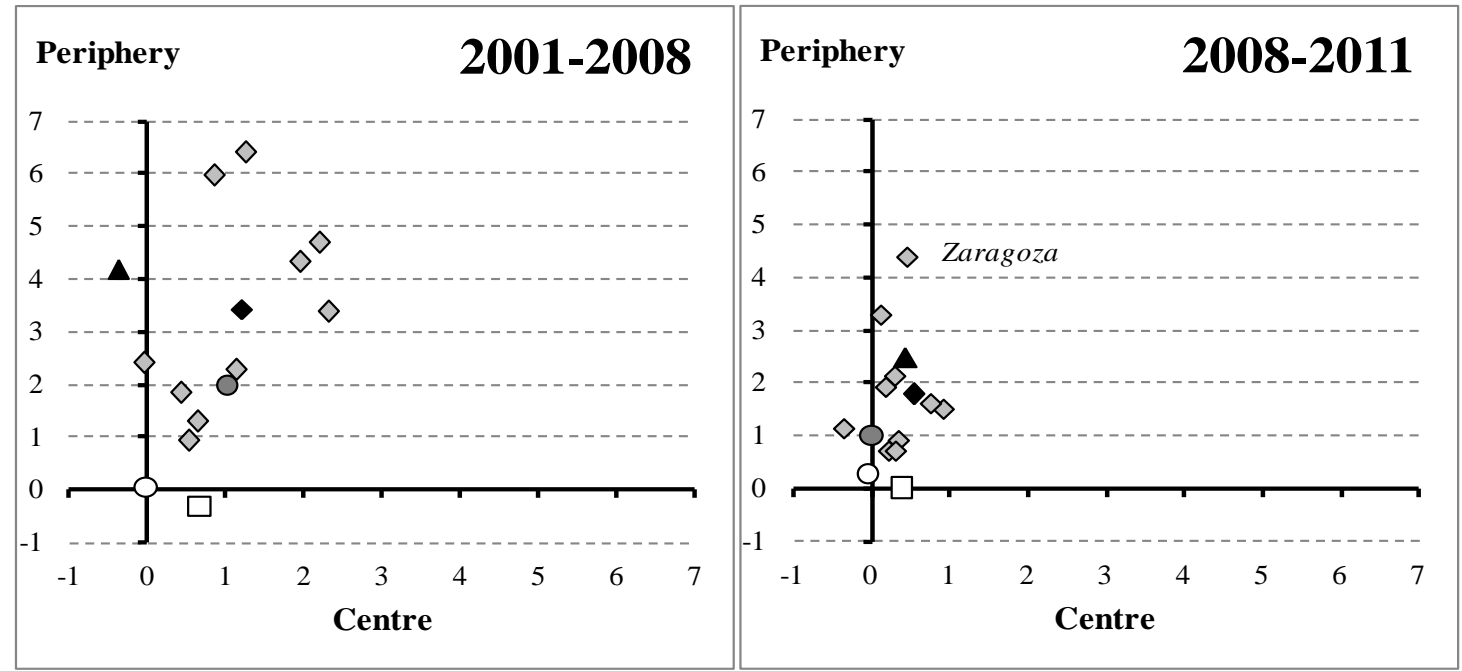

FOREIGN POPULATION

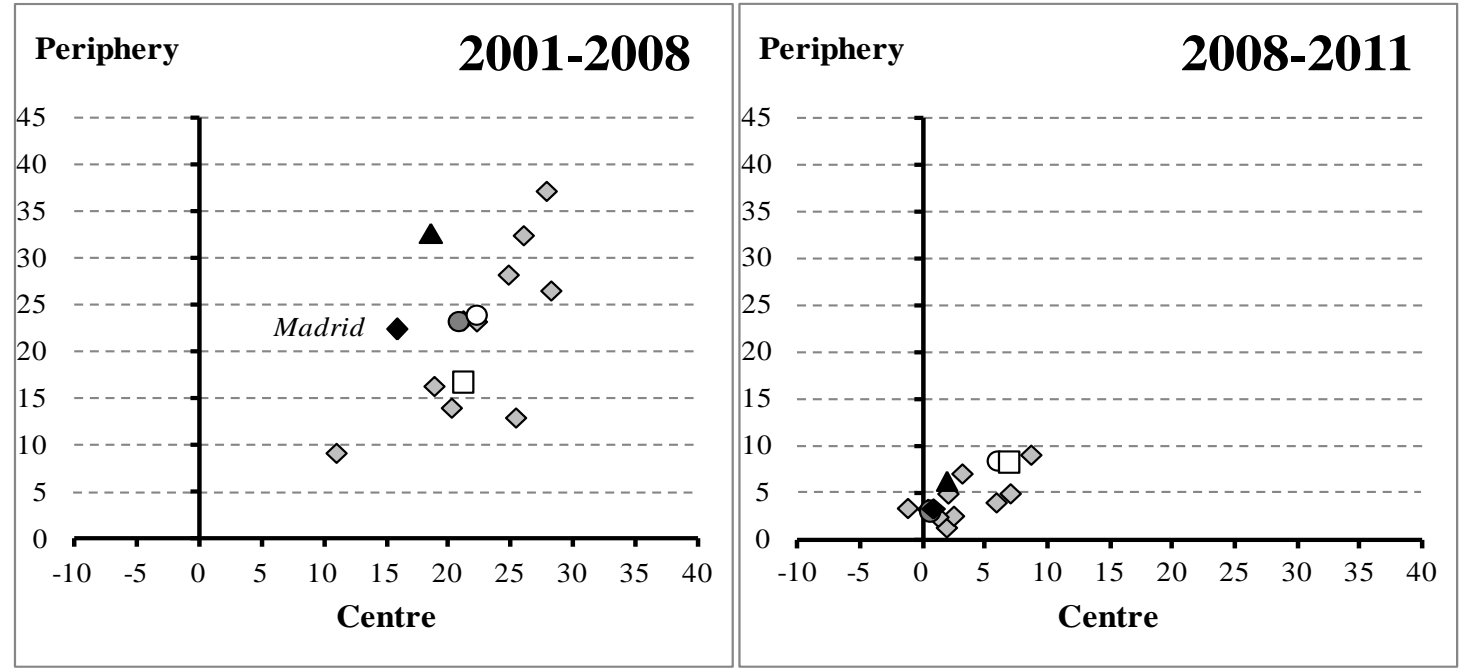

SPANISH POPULATION

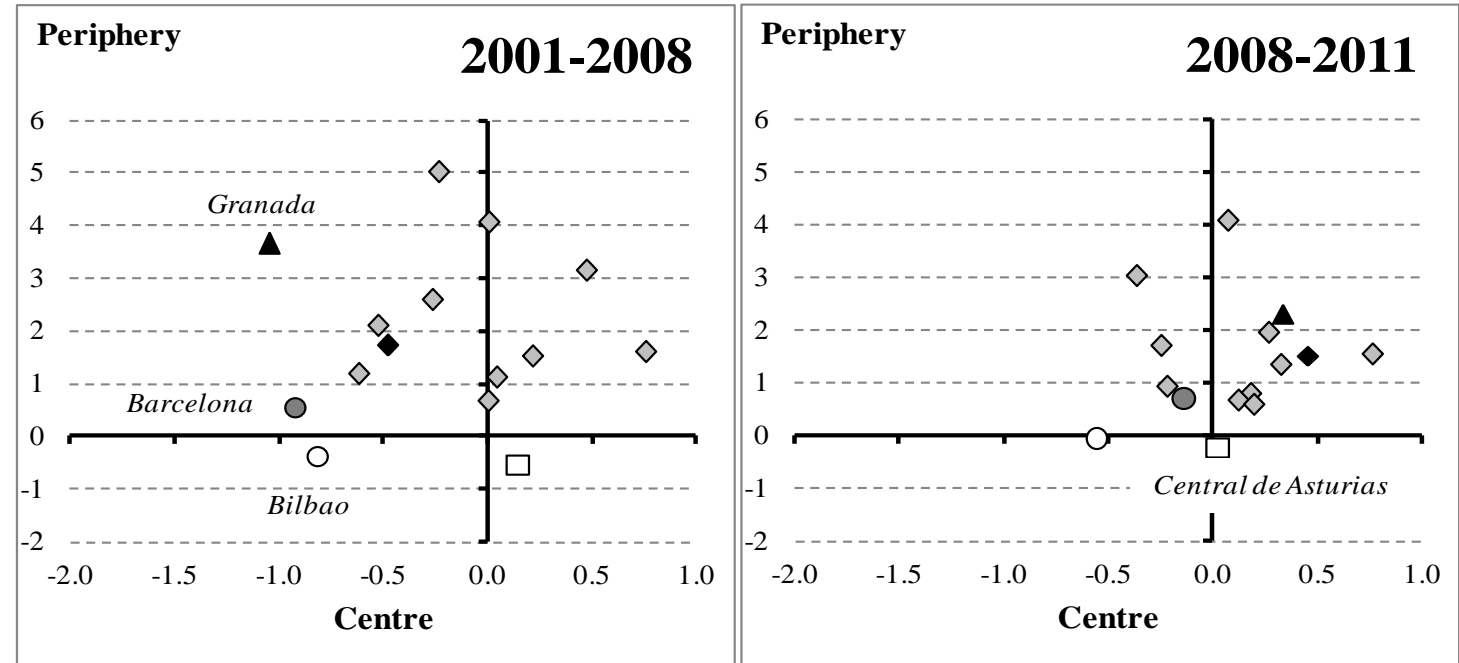

Figure 5. 2001-2008 and 2008-2011 centre and periphery Spanish metropolitan area annual cumulative growth rates ( $\mathrm{r} \%)$.

Source: INE 2001, 2008 and 2011 Padrón continuo. 
Table 1. Total, Spanish and foreign population growth in the 15 main Spanish metropolitan areas and in their cores and peripheries, 2001,2008 and 2011.

\begin{tabular}{|c|c|c|c|c|c|c|c|c|c|c|c|c|c|c|c|c|c|c|}
\hline \multirow[b]{4}{*}{ Alicante-Elche (6) } & \multicolumn{9}{|c|}{ Inhabitants (x1000) } & \multicolumn{6}{|c|}{ Growth rate $(\mathrm{r} \%)$} & \multicolumn{3}{|c|}{$\%$ foreigners } \\
\hline & \multicolumn{3}{|c|}{ Spanish } & \multicolumn{3}{|c|}{ Foreigners } & \multicolumn{3}{|c|}{ Total } & \multicolumn{2}{|c|}{ Spanish } & \multicolumn{2}{|c|}{ Foreigners } & \multicolumn{2}{|c|}{ Total } & \multirow[b]{2}{*}{2001} & \multirow[b]{2}{*}{2008} & \multirow[b]{2}{*}{2011} \\
\hline & 2001 & 2008 & 2011 & 2001 & 2008 & 2011 & 2001 & 2008 & 2011 & $2001-2008$ & 2008-2011 & 2001-2008 & $2008-2011$ & $2001-2008$ & 2008-2011 & & & \\
\hline & 555.8 & 592.6 & 603.1 & 16.7 & 93.2 & 95.6 & 572.5 & 685.8 & 698.7 & 0.92 & 0.59 & 27.85 & 0.84 & 2.61 & 0.62 & 2.9 & 13.6 & 13.7 \\
\hline Centre & 467.8 & 483.3 & 487.1 & 13.6 & 76.8 & 77.5 & 481.4 & 560.1 & 564.7 & 0.47 & 0.26 & 28.12 & 0.29 & 2.19 & 0.27 & 2.8 & 13.7 & 13.7 \\
\hline Periphery & 87.9 & 109.3 & 115.9 & 3.1 & 16.4 & 18.1 & 91.1 & 125.7 & 134.0 & 3.16 & 1.97 & 26.67 & 3.35 & 4.71 & 2.16 & 3.4 & 413.0 & 13.5 \\
\hline Central de Asturias (18) & 798.4 & 794.5 & 793.4 & 9.3 & 33.8 & 41.6 & $\mathbf{8 0 7 . 7}$ & 828.3 & 835.1 & -0.07 & -0.05 & 20.26 & 7.19 & 0.36 & 0.27 & 1.2 & 4.1 & 5.0 \\
\hline Centre & 546.5 & 552.1 & 552.5 & 7.3 & 27.8 & 34.0 & 553.8 & 579.9 & 586.6 & 0.15 & 0.02 & 21.14 & 6.97 & 0.66 & 0.38 & 1.3 & 5.1 & 5.8 \\
\hline Periphery & 251.8 & 242.4 & 240.8 & 2.0 & 6.0 & 7.6 & 253.9 & 248.4 & 248.5 & -0.54 & -0.22 & 16.77 & 8.20 & -0.31 & 0.01 & 0.8 & 2.5 & 3.1 \\
\hline Palma de Mallorca (8) & 415.0 & 426.5 & 434.1 & 32.8 & 106.2 & 114.1 & 447.8 & 532.7 & 548.2 & 0.39 & 0.59 & 18.28 & 2.43 & 2.51 & 0.96 & 7.3 & 19.9 & 20.8 \\
\hline Centre & 325.3 & 319.2 & 322.3 & 21.4 & 77.3 & 82.9 & 346.7 & 396.6 & 405.3 & -0.27 & 0.32 & 20.16 & 2.36 & 1.94 & 0.73 & 6.2 & 19.5 & 20.5 \\
\hline Periphery & 89.6 & 107.3 & 111.7 & 11.4 & 28.8 & 31.2 & 101.1 & 136.1 & 142.9 & 2.60 & 1.36 & 14.16 & 2.62 & 4.34 & 1.64 & 11.3 & 21.2 & 21.8 \\
\hline Barcelona (164) & 4220.6 & 4238.8 & 4295.4 & 169.8 & 690.0 & 733.8 & 4390.4 & 4928.9 & 5029.2 & 0.06 & 0.44 & 22.17 & 2.07 & 1.67 & 0.67 & 3.9 & 14.0 & 14.6 \\
\hline Centre & 1432.5 & 1342.7 & 1337.1 & 72.8 & 273.2 & 278.3 & 1505.3 & 1615.9 & 1615.4 & -0.92 & -0.14 & 20.80 & 0.62 & 1.02 & -0.01 & 4.8 & 316.9 & 17.2 \\
\hline Periphery & 2788.0 & 2896.1 & 2958.2 & 97.0 & 416.8 & 455.5 & 2885.1 & 3312.9 & 3413.7 & 0.54 & 0.71 & 23.15 & 3.00 & 2.00 & 1.00 & 3.4 & 12.6 & 13.3 \\
\hline Bilbao (35) & 894.5 & 860.3 & 854.0 & 10.8 & 46.1 & 56.6 & 905.4 & 906.4 & 910.6 & -0.55 & -0.25 & 22.96 & 7.11 & 0.02 & 0.15 & 1.2 & 5.1 & 6.2 \\
\hline Centre & 347.8 & 328.4 & 323.0 & 6.1 & 24.9 & 29.7 & 353.9 & 353.3 & 352.7 & -0.82 & -0.55 & 22.21 & 5.99 & -0.02 & -0.06 & 1.7 & 7.1 & 8.4 \\
\hline Periphery & 546.7 & 531.9 & 531.0 & 4.7 & 21.1 & 26.9 & 551.4 & 553.1 & 557.9 & -0.39 & -0.06 & 23.89 & 8.39 & 0.04 & 0.29 & 0.9 & 3.8 & 4.8 \\
\hline Bahía de Cádiz (6) & 581.5 & 615.4 & 624.2 & 3.7 & 15.4 & 18.3 & 585.2 & 630.8 & 642.5 & 0.81 & 0.47 & 22.44 & 5.81 & 1.08 & 0.61 & 0.6 & 2.4 & 2.8 \\
\hline Centre & 321.3 & 326.1 & 327.8 & 1.7 & 6.5 & 7.9 & 323.1 & 332.6 & 335.8 & 0.21 & 0.17 & 21.10 & 6.90 & 0.41 & 0.32 & 0.5 & 1.9 & 2.4 \\
\hline Periphery & 260.1 & 289.3 & 296.4 & 2.0 & 8.9 & 10.4 & 262.2 & 298.3 & 306.8 & 1.53 & 0.81 & 23.48 & 5.01 & 1.86 & 0.94 & 0.8 & 3.0 & 3.4 \\
\hline Vigo-Pontevedra (14) & 546.0 & 555.1 & 560.7 & 7.8 & 25.0 & 27.1 & 553.8 & 580.1 & 587.8 & 0.24 & 0.34 & 18.20 & 2.66 & 0.67 & 0.44 & 1.4 & 4.3 & 4.6 \\
\hline Centre & 357.4 & 357.4 & 359.4 & 5.7 & 19.1 & 20.2 & 363.1 & 376.5 & 379.6 & 0.00 & 0.19 & 18.78 & 1.91 & 0.52 & 0.28 & 1.6 & 5.1 & 5.3 \\
\hline Periphery & 188.5 & 197.7 & 201.3 & 2.0 & 6.0 & 6.9 & 190.6 & 203.7 & 208.2 & 0.68 & 0.60 & 16.48 & 4.99 & 0.95 & 0.74 & 1.1 & 2.9 & 3.3 \\
\hline Granada (30) & 430.7 & 468.5 & 488.1 & 6.1 & 26.3 & 29.4 & 436.8 & 494.8 & 517.6 & 1.21 & 1.38 & 23.13 & 3.77 & 1.80 & 1.51 & 1.4 & 5.3 & 5.7 \\
\hline Centre & 238.7 & 221.8 & 224.0 & 4.6 & 15.2 & 16.1 & 243.3 & 237.0 & 240.1 & -1.04 & 0.33 & 18.64 & 1.93 & -0.38 & 0.44 & 1.9 & 6.4 & 6.7 \\
\hline Periphery & 191.9 & 246.7 & 264.1 & 1.5 & 11.1 & 13.3 & 193.5 & 257.8 & 277.5 & 3.65 & 2.30 & 32.63 & 6.19 & 4.18 & 2.48 & 0.8 & 4.3 & 4.8 \\
\hline
\end{tabular}


Table 1. Total, Spanish and foreign population growth in the 15 main Spanish metropolitan areas and their cores and peripheries, 2001,2008 and 2011 (cont.).

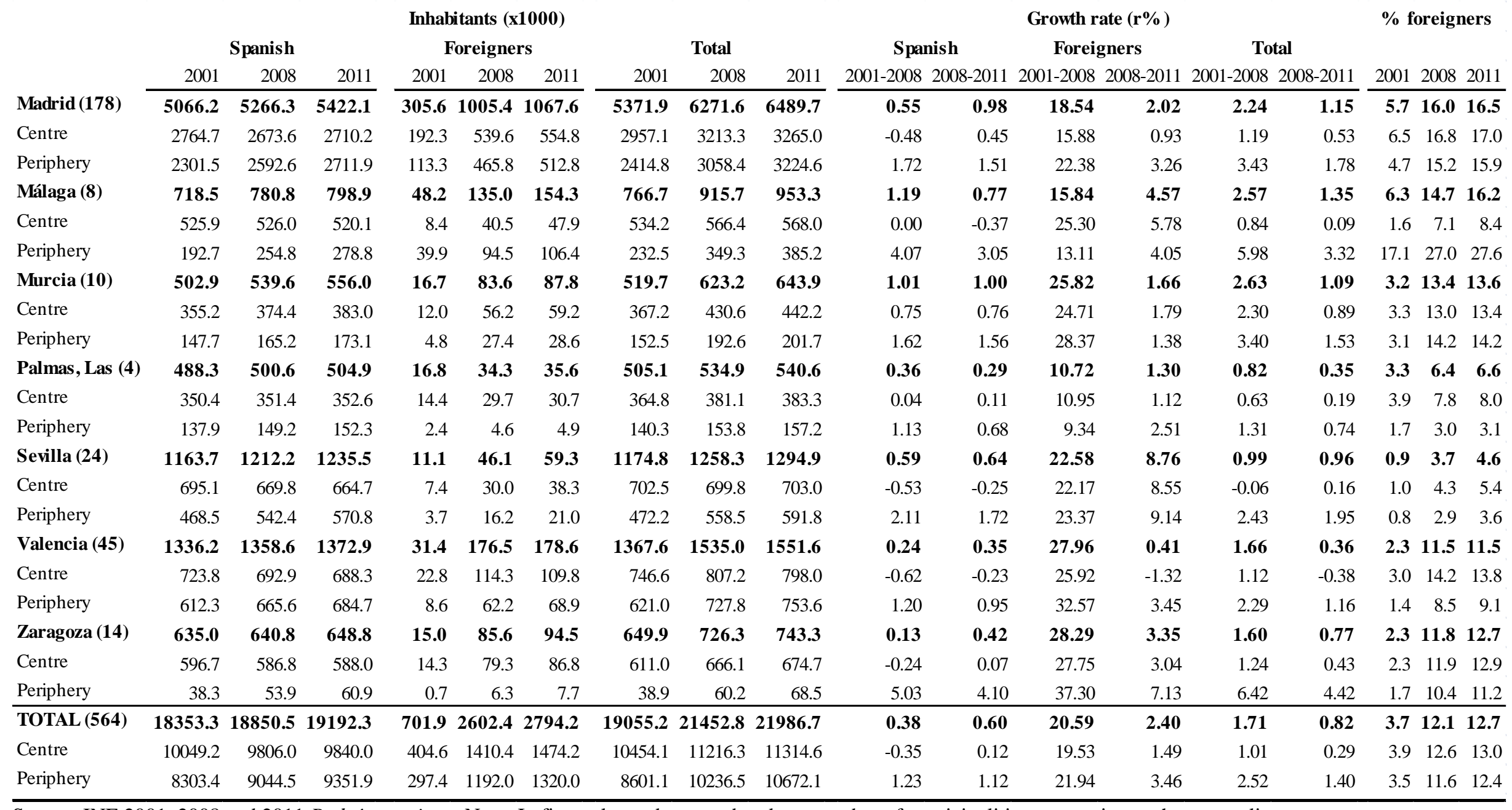

Source: INE 2001, 2008 and 2011 Padrón continuo. Note: In first column, between brackets, number of municipalities composing each metropolitan area. 
Table 2. Main Spanish metropolitan area typology according to diverse 2001-2011 growth indicators.

\begin{tabular}{lrrrrrrrr} 
& \multicolumn{2}{c}{ Annual growth rate (\%) } & \multicolumn{2}{c}{ \% foreig people } & \multicolumn{2}{c}{ Natural growth rate (\%) } & \multicolumn{2}{c}{ Migratory growth rate (\%) } \\
& \multicolumn{2}{c}{$\mathbf{2 0 0 1 - 2 0 1 1}$} & \multicolumn{2}{c}{$\mathbf{2 0 1 1}$} & \multicolumn{2}{c}{$\mathbf{2 0 0 1 - 2 0 1 1}$} & \multicolumn{2}{c}{$\mathbf{2 0 0 1 - 2 0 1 1}$} \\
& Core city & Periphery & Core city & Periphery & Core city & Periphery & Core city & Periphery \\
Category 1 & 1.25 & 2.80 & 15.93 & 14.64 & 2.25 & 5.51 & 8.46 & 18.26 \\
Category 2 & 0.80 & 5.50 & 10.65 & 19.42 & 2.09 & 6.72 & 5.85 & 46.19 \\
Category 3 & 0.24 & 1.92 & 5.57 & 3.63 & 1.88 & 5.49 & 0.49 & 13.05 \\
Category 4 & 0.30 & -0.05 & 7.11 & 3.94 & -2.31 & -2.29 & 4.99 & 1.79 \\
TOTAL & $\mathbf{0 , 7 9}$ & $\mathbf{2 , 1 8}$ & $\mathbf{1 3 . 0 3}$ & $\mathbf{1 2 . 3 7}$ & $\mathbf{1 . 3 8}$ & $\mathbf{5 . 5 0}$ & $\mathbf{6 . 0 4}$ & $\mathbf{1 5 . 3 4}$ \\
\hline
\end{tabular}

Source: INE 2001 and 2011 Padrón continuo and 2001-2010 Movimiento Natural de la Población. 